\title{
The unique Abramovka REE-rich mineralization is a potential source of REE for the Pavlovsk coals deposit (Primorsky Krai, Russia)
}

\author{
Igor Chekryzhov ${ }^{1,2, *}$, Irina Tarasenko ${ }^{1,2}$, Elena $\mathrm{Vakh}^{2}$, and Sergey Vysotsky $y^{1,2}$ \\ ${ }^{1}$ Far East Geological Institute, Vladivostok, Russia \\ ${ }^{2}$ Far Eastern Federal University, Vladivostok, Russia
}

\begin{abstract}
The unique REE mineralization of the Abramovka ore occurrence, associated near-surface waters, and REE-rich coals of the Pavlovka basin were studied. The authors, on the base of new isotopegeochemical data and K-Ar dating, suggest that the Abramovka REE minerals (hydrocarbonates, hydrophosphates and hydroxides) formed as a result of interaction of the Palaeozoic metasedimentary and Mesozoic volcanic rocks with near-surface waters. In the Pavlovka metalliferous coals, REE are concentrated predominantly in a humic matter that sorbed REE from water solutions during the peat accumulation stage. A similar distribution of REE in the Abramovka ores, associated near-surface waters, and metalliferous coals of the Pavlovka basin suggest that the Abramovkatype mineralization might be a major source of REE enrichment in the Pavlovka coals.
\end{abstract}

\section{Introduction}

A unique REE-rich (REE $>11 \%$ ) mineralization was found in the eastern border of the Pavlovka coal-bearing depression (Mikhailovsky District of Primorsky Krai) in an open pit for road fill stones (Abramovsk ore occurrence) [1]. A potentially commercial mineralization (REE $>0.1 \%$ ) is also discovered in some coal seams of the Pavlovka lignite deposit which is located nearby [2, 3, 4] (Fig. 1) The relation between these REE manifestations are under discussion now. This work geochemically compares the Abramovka ores, metalliferous coals of the Pavlovka deposit, and associated near-surface waters to understand if there is a genetic connection between them.

\section{Results and Discussion}

Both metasedimentary and magmatic formations take part in the geological structure of the Abramovka rare-metal occurrence. Lower Cambrian rocks of the Luzanovskaya suite with two sub-suites occur there. The lower sub-suite is represented by alternating siltstones and laminated slates with black slate lenses and layers. All the rocks are pyritized. The upper

* Corresponding author: chekr2004@mail.ru 
sub-suite is predominated by dark gray and black schungite slates with siltstone and sandstone interbeds and carbonate lenses. The upper sub-suite rocks are strongly argillized. The argillization depth is up to $63 \mathrm{~m}$ from the surface. The Lower Cambrian deposits are injected by dolerite dikes of the north-western extension which are also deeply argillized in the near-surface parts. The age of the dikes was earlier considered as Late Cenozoic [1].

Recently the Abramovka REE ores have been explored. Some ore bodies were outlined on the surface and to the depth. Their interrelations with the argillization zones in the metamorphized silicate-carbonaceous slates of the upper sub-suite of Luzanovskaya suite and basaltic dikes was determined. Rare-earth minerals in the Abramovsk occurrence are predominately presented by aqueous carbonates (kimuraite with little admixture of lokkaite and neodime lanthanite) (Fig. 2) and phosphates (churchite and rhabdophanite). Similar association of the rare-earth carbonates was previously found only in Japan, on Kushu Island in pores and cracks of the Higashi-Matsuura olivine basalts [5] (Fig. 1). REE-bearing minerals like apatite and aluminophosphates were also found in the Abramovka occurrence in small quantities. Up to $20 \%$ of REE in the ores are in the sorbed form. These rich REE ores with REE contents up to 11.2 mass $\%$, including $\mathrm{Y}$ up to 6.6 mass $\%$ are unique and have not been met before in the world.
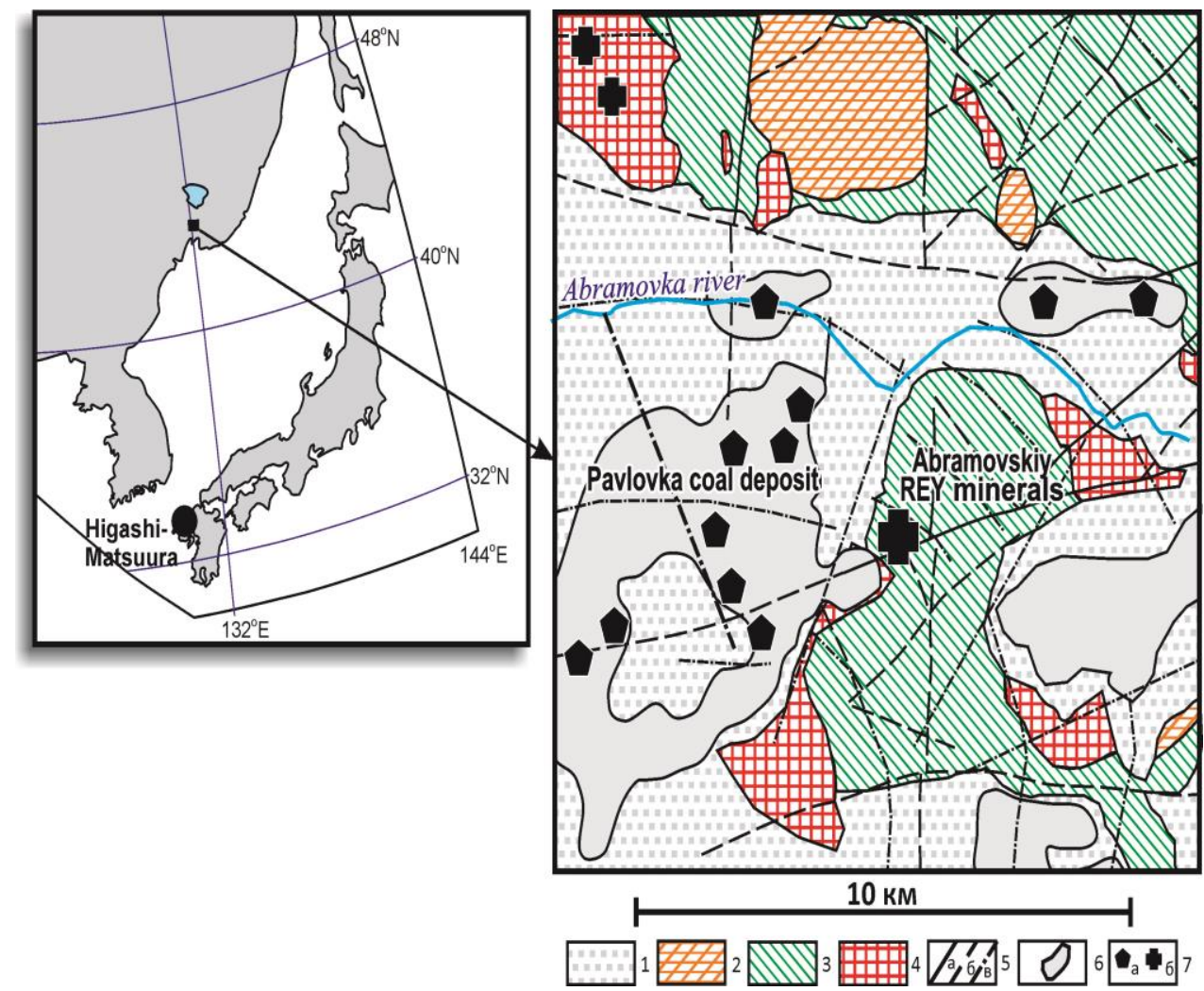

Fig. 1. Scheme of the geological structure and mineralization of the eastern part of the Pavlovsk depression: 1 - Cenozoic terrigenous deposits $\left(\mathrm{Pg}_{2}-\mathrm{N}_{2}\right) ; 2$ - Paleozoic felsic effusives and extrusions; 3 - Paleozoic terrigenous-carbonate sequences; 4 - Paleozoic granite and granosyenite intrusions; 5 faults: defined (a), supposed (b), according to satellite's photo interpretation (c); 6 - coal-bearing areas; 7 - rare-metal occurrences in the Cenozoic coal-bearing depressions (a) and crystalline rocks (b). 

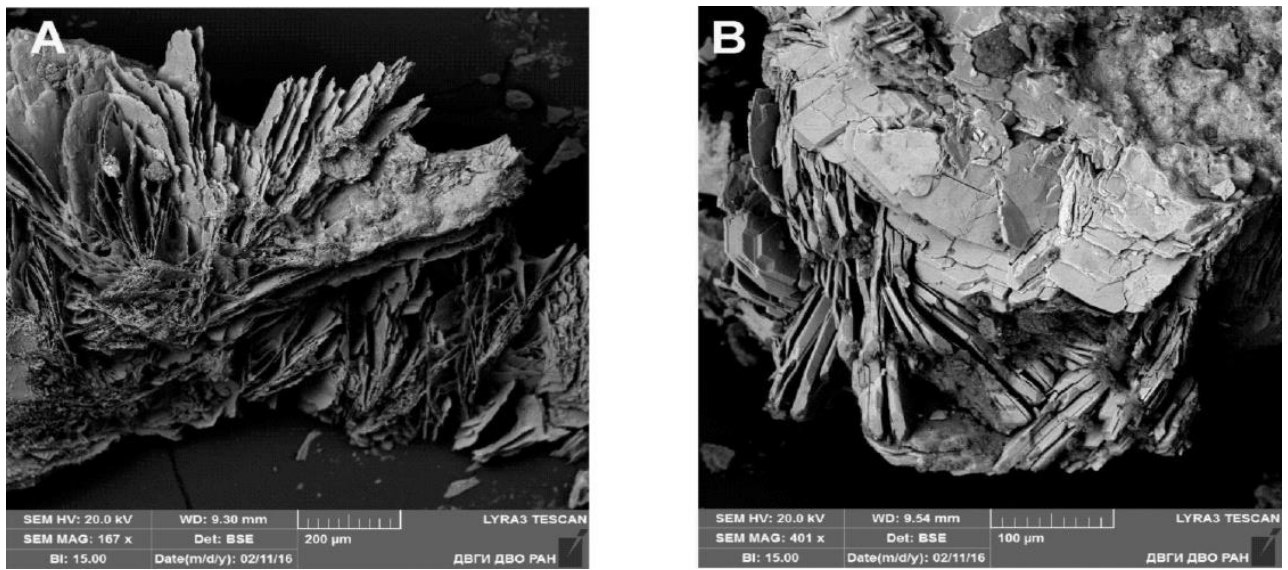

Fig. 2. Rare-earth minerals of the Abramovsk occurrence: A - kimuraite, B - Nd-lanthanite).

The Abramovka occurrence was earlier supposed to consist of rich ores forming a steeply dipping stockwork (some meters across) associated with poor ores, that was interpreted as a volcanic diatreme surrounded by slope sediments. However, this interpretation has not found its confirmation later.

The recent exploration drilling showed that the Abramovka REE mineralization did not occur below the near-surface weathering (argillization) zone. Results of our research were also unexpected. First of all, the K-Ar dating determined the early Triassic age $(241 \pm 7$ Million years) of dolerites forming a net of dikes inside and around the ore bodies. The SHRIMP dates of zircons from the deeply argillized rocks showed a wide range of ages from 533 to 398 Million years. The isotopic ratio of $\mathrm{Nd}$ and $\mathrm{Sr}$ in the lanthanite of the Abramovka occurrence $\left({ }^{143} \mathrm{Nd} /{ }^{144} \mathrm{Nd}=0.512133 \pm 6,{ }^{87} \mathrm{Sr} /{ }^{86} \mathrm{Sr}=0.71361 \pm 8\right.$ [7] $)$ also clearly indicates the upper-crustal origin of the ore components. All these data suggested that the studied argillization replaced tectonic breccia composed of fragments of the LowerPaleozoic slates and Middle-Paleozoic and early Mesozoic mafic dikes, but not a young diatreme as supposed earlier. Secondly, our new isotope-geochemical data showed important role of exogenous process in the formation of the rare-earth mineralization $[2 ; 3$; $6,8]$. Low values of $\delta^{13} \mathrm{C}\left(-19.8--15.8 \%\right.$ ) and high values of $\delta^{18} \mathrm{O}(14.7-25.5 \%)$ testify to near-surface conditions of the formation of the rare-earth carbonates of the Abramovsk occurrence. Thus, the rare-earth ores the Abramovsk occurrence, appeared in that way and localized within the argillization zones of initially quite REE-enriched rocks, are located in the right border of the Pavlovka depression. The Eocene-Oligocene coals of this depression are enriched in many chemical elements including the rare-earth ones [4; 5]. A predominant part of REE in the coals of Pavlovka deposit is concentrated in the humic matter and seems to be carried with water solutions at the stage of peat accumulation and further sedimentary bed subsidence [9]. It is confirmed by the geochemical studies of modern water draining the Abramovka occurrence and accumulated at the bottom of its open pit, the regional fresh waters, as well as the coal ash of the Pavlovka deposit.

The water, which drains the hypergenesis zone of the Abramovsk occurrence and then accumulates in the open-pit pool, has low $\mathrm{pH}$ value (2.1-2.9), high concentrations of $\mathrm{SO}_{4}$ (1041-1100 mg/L), Mg (96.81-101.2 mg/L), Ca (94.48-97.36 mg/L), Fe (9.91-10.55 $\mathrm{mg} / \mathrm{L}), \mathrm{Mn}(11.72-12.39 \mathrm{mg} / \mathrm{L})$, and anomalous enrichment in REE ( $\sum \mathrm{REE}=1201.6$ $\mu \mathrm{g} / \mathrm{L})$, especially La $(138.5-179.9 \mu \mathrm{g} / \mathrm{L})$ and $\mathrm{Y}(306.4-357.0 \mu \mathrm{g} / \mathrm{L})$.

The study of REE distribution in the Abramovka occurrence ores, the coal ash of the Pavlovsk deposit, the open-pit water, and the Abramovka-river water normalized to the North American Shale Composite showed that all studied subjects had similar patterns of the REE and Y distribution. (Fig. 3). These data can testify that over the evolution of the 
Pavlovsk depression, complex and diverse processes of the water migration of chemical elements have occurred. Acidification of the sulfide minerals of the lower Luzanovskaya suite slates in the Abramovka deposit hypergenesis zone contributed to the formation of acid waters, which leached the bedrocks and unstable REE carbonates. These waters were saturated by major and trace elements, including REE, transported them to the nearest peat bog where they were sorbed by organic matter. This seems to be a reasonable explanation for the formation of the REE-enriched coals of the Pavlovka deposit.

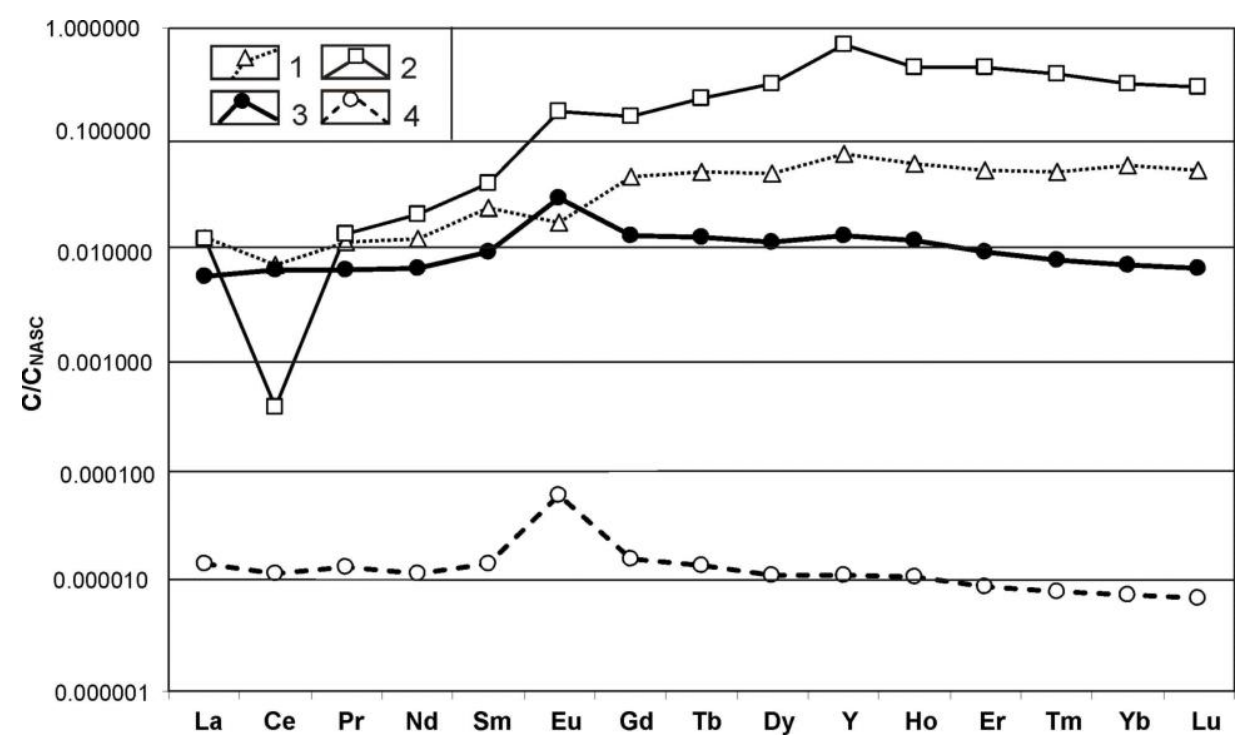

Fig. 3. Spectra of the REE distribution in the rocks and waters of the Abramovka ore occurrence and Pavlovka coal deposit, normalized to the North American Shale Composite (NASC) [10]: 1 - coal ash of the Pavlovka deposit; 2 - Abramovka occurrence ore; 3 - Abramovka open-pit water; 4 Abramovka river water.

\section{Conclusions}

Our study suggests that the rare-earth mineralization of the Abramovka occurrence formed due to dissolution of the rock-forming and ore minerals of the Palaeozoic metasedimentary and Mesozoic volcanogenic rocks by the near-surface waters. Intensive saturation of the infiltration water with some major and trace elements, including REE, in the near-surface conditions contributed to the deposition and concentrating of REE hydrocarbonates, such as kimuraite and neodyme lanthanite. Further, along with the growth of the solution mineralization and change of the water chemical conditions, the carbonate association was accomplished by phosphates, such as churchite and rhabdophanite. As a results, the rich rare-earth ores of the Abramovka deposit have been localized within the argillization zones of the initially quite REE-enriched rocks. Locating in the eastern border of the Pavlovka depression including lignite deposit they seem to be the main source of the hydrogenic metal-bearing of the coals of the eastern part of the Pavlovsk deposit. Dissolving of the sulfide minerals of the pyritized slates of lower Luzanovskaya sub-suite in the hypergenesis zone contributed to the formation of acidic water which actively leached and solved the rocks and transported some major and trace elements, including REE, to the nearest peat bog. There they were sorbed by organic matter with further formation of the metal-bearing coals. 
Acknowledgments. The research was carried out under support of the grant of Russian Scientific Fund (No. 18-17-00004) and of the Russian Foundation for Basic Research (project No. 17-0500051a).

\section{References}

1. V. Seredin. Geol. Ore Deposits, 40, 357-371 (1998)

2. I. Chekryzhov, G. Trach, V. Nechaev, D. Trach Gorny journal, № 2, 35-40 (2018) (in Russian)

3. V. Seredin, S. Dai. Int. J. Coal Geol., 94 (2012)

4. S. Dai, I. Chekryzhov, V. Seredin, V. Nechaev, I. Graham, J. Hower, C. Ward, D. Ren, X. Wang. Gondwana Res., 29, 67-93 (2016)

5. K. Nagashima, R.Miyawaki, J. Takase, I. Nakai, K. Sakurai, S. Matsubara, A. Kato, S. Iwano. Amer. Mineralogist, 71, 1028-1033 (1986)

6. I. Chekryzhov, V. Nechaev, I. Tarasenko, S. Vysotsky. Proceedings of the 4th AllRussian scientific conference "Geological processes in subduction, collision, and sliding lithospheric plates environments”, 310-313 (2018) (in Russian).

7. V. Seredin, A. Kremenetskii, G. Trach, I. Tomson. Dokl. Earth Sci., 425, 403-408 (2009)

8. V. Nechaev, I. Chekryzhov, S. Vysotskiy, A. Ignatiev, T. Velivetskaya, I. Tarasenko, A. Agoshkov, Ore Geology Reviews, 103, 68-77 (2018)

9. V. Seredin, M. Shpirt, Rare-earth elements in humic matter of metal-bearing coals. Lithol. Miner. Resour., 34 (3), 244-248 (1999)

10. L. Gromet, L. Haskin, R. Korotev, R. Dymek, Geochimica et Cosmochimica Acta, 48, 2469-2482 (1984) 